\title{
Inflammatory Response and Acute Phase Proteins in the Transition Period of High-Yielding Dairy Cows
}

\author{
Erminio Trevisi ${ }^{1}$, Massimo Amadori ${ }^{2}$, Ivonne Archetti2 ${ }^{2}$ \\ Nicola Lacetera ${ }^{3}$ and Giuseppe Bertoni ${ }^{1}$ \\ ${ }^{1}$ Istituto di Zootecnica, Università Cattolica del Sacro Cuore, Piacenza \\ ${ }^{2}$ Laboratory of Cellular Immunology, Istituto Zooprofilattico \\ Sperimentale della Lombardia e dell'Emilia-Romagna, Brescia \\ ${ }^{3}$ Dipartimento di Produzioni Animali, \\ Università della Tuscia, Viterbo \\ Italy
}

\section{Introduction}

Dairy cows undergo tremendous adaptive changes during the transition from late gestation to early lactation (Drackley et al., 2005). The importance of the periparturient period in determining health, productivity and profitability has been accurately described by Grummer (1995), Goff \& Horst (1997), Drackley (1999) and Drackley et al. (2005).

Many are in fact the metabolic and microbial diseases typical of this period: milk fever, metritis, rumen acidosis, lameness (Drackley, 1999). Furthermore, the well known reduction of immune competence increases the susceptibility to mastitis and other infections. The risk of diseases seems to be increased as much as milk yield is genetically increased (Müller et al., 1999). This could be due to the metabolic stress consequences of high milk yield compared with nutrients intake, which is likely the cause of an impairment of the defence systems (Pond \& Newsholme 1999). Another possibility, suggested by Drackley et al. (2005), is that multiple stressors, as much as they are severe and prolonged, can divert enough resources (energy, amino acids, etc.) and cause immune system depression. This mechanism could account for the increase of risks in case of poor management, heat stress conditions, excessive rain and mud, etc.

The hypothesis of multiple stressors combined with the general observation that many cows, in the same farm, are able to meet the challenge of the transition period, suggests that a genetic component is important for metabolic adaptation and, contemporaneously, that an improved management of farms could reduce the risks of affections. Therefore, according to Goff \& Horst (1997), "the well-being and profitability of the cow could be greatly enhanced by understanding those factors that account for the high disease incidence in periparturient cows". Regarding these aspects, particularly intriguing are the following issues:

- how do some metabolic diseases increase the risk (Erb \& Gröhn, 1988) of further metabolic and microbial diseases? 
- $\quad$ how is the immune system depressed, considering that signs of disregulated responses can be detected even before calving, when energy balance is still positive?

- $\quad$ which role is played by the dry matter intake (DMI) as well as the energy efficiency in early lactation and which mechanisms determine their changes? Namely, why is DMI more or less depressed in the last days of the "dry" period before calving and, thereafter, its rate of increase is often not related to milk yield?

\subsection{Inflammation in the periparturient period}

Unfortunately, we do not have an answer to all the above questions; yet, there is evidence that inflammatory phenomena could provide a suitable conceptual framework for several of them:

- Cappa et al. (1989) showed the appearance of clinically overt inflammatory problems after calving (30\% in a farm and $100 \%$ in another one);

- Bertoni et al. (1997) showed a positive relationship between haptoglobin at day in milk (DIM) 15 and both days open (calving to conception) and culling rates of cows, particularly in case of high genetic merit (Calamari et al., 1997);

- Trevisi et al. (1998) showed that early lactating cows with a lower liver synthesis activity were less fertile (137 vs. 89 days from calving to conception). The low liver activity was indexed by lower levels of albumin, Retinol Binding Protein - RBP - and lipoproteins. Probably, this activity is linked to inflammatory disorders because concomitantly high haptoglobin and globulin levels were also observed;

- Trevisi et al. (2001) evaluated the inflammatory response after calving on the basis of the blood levels of albumin, vitamin A (RBP index) and total cholesterol (lipoprotein index) and developed a composite Liver Activity Index (LAI): the lower the index, the higher the inflammatory condition (as shown by +APP changes).

- Bertoni et al. (2008) retrospectively separated parturient cows of 5 herds in accordance with LAI values in the 1st month of lactation. Results were very interesting, in fact cows with low LAI values (the lower quartile of the cows under study) showed:

- $\quad$ higher frequency of clinical symptoms (42\% vs $5 \%$ for LO-LAI and UP-LAI groups respectively) and often more than one disease case per cow;

- less milk yield and reduced fertility;

- higher haptoglobin peaks after calving, confirming the more severe inflammation, also observed in cows without clinical symptoms;

- a larger energy deficiency, despite the lower milk yield, as confirmed by the more accentuated losses of body condition score (BCS) and the higher levels of betahydroxy-butyrate. Interestingly, the worse negative energy balance (NEB) could be due to a lower DMI, as suggested by the lower plasma levels of urea; in fact, uremia is related to total protein intake and therefore - in a population fed the same Total Mixed Ratio (TMR) - to DMI;

- a lower energy efficiency utilization, as likely result of the increased maintenance cost necessary to support immune system activity (Trevisi et al., 2007; Trevisi et al. 2010b);

- Trevisi et al. (2010c) showed that cows with a higher inflammatory response after calving are characterized by pronounced differences of inflammatory markers in the previous dry period too [e.g. higher levels of sialic acid and Reactive Oxygen Metabolites (ROM) and lower ones of RBP, cholesterol, haemolytic complement]. 
The occurrence of inflammatory conditions in periparturient dairy cows and their consequences were also confirmed ex iuvantibus. Consistent results have been obtained by the authors following administration of acetylsalicylate (i.m. or by os) in apparently healthy cows at calving time, to prevent and/or to treat possible sub-clinical inflammatory conditions. In fact, the incidence of clinical disorders and the severity of the inflammatory response after calving were reduced in treated cows and, most important, milk yield and fertility were significantly improved (Bertoni et al., 2004; Trevisi \& Bertoni, 2008; Trevisi et al., 2008a). Analogous results were also observed using both phytoextracts (showing immunomodulatory and antinflammatory properties) and anti-Endotoxin serum. Namely, diet supplementation with Echinacea angustifolia, over 3-4 weeks around calving, seems able to attenuate some typical adverse effects of inflammation around calving and to improve energy metabolism (Trevisi et al., 2008b). Nevertheless, the presence of some contradictory aspects (e.g. marked post calving rise of plasma haptoglobin) suggests the need for further investigations. Treatment with an anti-Endotoxin serum immediately before calving did not reduce the prevalence of disease cases in the transition period, but attenuated the response to the disease stress and anyway improved reproductive activity and conception rates (Bertoni et al., 2003).

In other trials, treatments with antibiotics immediately before calving (Bertoni et al., 2003) failed to improve performance and to reduce disease prevalence at the beginning of lactation. Furthermore, the anticipation of acetylsalicylate treatments before calving did not show encouraging results, in that the incidence of health disorders was not reduced and the attenuation of inflammation appeared less evident in comparison to acetylsalicylate treatments after calving (Trevisi et al., 2008). Moreover, oral, low-dose treatments with IFNa (a cytokine that exerts anti-inflammatory effects in monogastric species) in late gestation also failed to reduce inflammation after calving. Contrariwise to the supposed effect, IFN- $a$ caused an increased inflammatory response after calving, with consequent reduction of milk yield and a worsening of performance, suggesting a pro-inflammatory effect in ruminants; the possible causes of this phenomenon were illustrated by the authors in a previous study (Trevisi et al., 2009).

The above displayed results clearly suggest that calving time is accompanied by more or less serious inflammatory conditions, often without clinical symptoms. Furthermore, these conditions could negatively affect metabolism, health and reproductive activity of cows. The possible mechanism is the liver synthesis deviation (from usual to acute phase proteins), reduction of DMI and energy efficiency, thus negative energy balance (NEB) and its consequences (immune system impairment, delay of reproductive resumption, etc.). Nevertheless, it remains a major question: which is (are) the cause(s) of these inflammations?

\subsection{Possible causes of inflammation in dairy cattle, with particular attention to the transition period}

Inflammation is a well known condition - described by Celsus (50 BC) - characterized by "rubor et tumor cum calore et dolore". It was suggested to be caused by tissue damage and infections, although many types of injury produce a similar inflammatory response (Hunter, 1794; cited by Grimble, 2001). It is in fact noteworthy that different types of injuries (e.g. trauma, burns, exposure to noxious chemicals, etc.), as well as various stresses (e.g. oxidation, heat, intense physical exercise etc.) in addition to autoimmune diseases, cancer, some toxic substances, can be responsible for an inflammatory response (figure 1). 
Moreover, very peculiar is the possibility of endotoxins (LPS) and/or bacteria passing through the digestive channel wall, when its barrier function is damaged for different reasons: excessive fermentation, ischemia-reperfusion etc. (Rowlands and Gardiner, 1998). Inflammation process is also termed as acute-phase response (Richard and Gauldie, 1995), and comprises immediate events localized at sites of damage as well as an activation of systemic phenomena mediated by cytokines. A counter-regulatory system plays a critical role during APR in preventing the host from mounting an excessive defence response (Kapcala, 1999), which would be dangerous. A large variety of leukocyte and non-leukocyte cell types are able to synthesize either pro-inflammatory cytokines (e.g. IL-1, IL-6 and TNFa), which promote local and systemic responses (Cousins, 1985; Dinarello, 1997; Elsasser et al., 1997; Gruys et al., 1999), or anti-inflammatory cytokines (e.g. IL-4, IL-10), which depress the activity of the former to avoid dangerous side effects (Grimble, 2001). Thereafter, some cytokines initiate the cascade of inflammatory mediators targeting the endothelium, and causing the release of eicosanoids (prostaglandins, leukotrienes, lipoxins, etc.) by activation of the cyclo-oxygenase-2. Eicosanoids are the main mediators of inflammation and justify the typical clinical symptoms of this process.

Inflammation can be triggered by several factors that often occur in the transition period (Drackley, 1999). In this phase, any type of disorder, although apparently modest or originated from apparently not so dangerous agents (e.g. common parasites or infections, modest lesions or injuries, little diet mistakes, grouping and movement of cows, deficiency in housing), could be conducive to more severe affections in the whole transition period if the usual homeostatic adaptation strategies fail. Peculiar causes of inflammation during the transition period could be the following:

- mammary gland differentiation and proliferation;

- uterus and placenta interactions;

- physical effort during the calving as well as possible traumas consequent to difficult or abnormal calving (dystocia);

- immunosuppression, as possible reason of more frequent infections.

Moreover, different clinically adverse events could interact and progressively magnify each other, allowing for the development of secondary forms before or after calving (i.e. respiratory affections, ketosis and/or liver lipidosis, metritis, laminitis, mastitis etc.). Furthermore, any activating stimulus of inflammation causes an up-regulation of inflammatory gene expression, mostly through activation of Nuclear Factor-kB (NF-kB), a transcription factor associated with inflammation (Lindström \& Bennett, 2005), and in particular to the expression of the relevant pro-inflammatory genes. Consequently, NF-kB up-regulates the release of pro-inflammatory cytokines as well as the release of several other proteins related to inflammation (e.g. monocyte chemoattractant Protein-1, the inducible isoform of cyclo-oxygenase, an inducible form of nitric oxide synthase, NOS-2, with higher nitric oxide production, adhesion molecule ICAM-1; Elewaut et al., 1999). Thus, proinflammatory cytokines would be responsible of their further synthesis and, hence, of the amplification of inflammation itself. Therefore, inhibitors of NFkB (e.g. cortisol, antioxidants, $\omega 3$ fatty acids, etc.) are useful to stop inflammation.

\subsubsection{Mammary gland}

In the last 2 weeks of pregnancy, in coincidence with mammary gland development a small rise of body temperature (about $+0.3-0.5^{\circ} \mathrm{C}$ ) and sometime a slight rise of plasma haptoglobin levels are usually observed; this could be one of the first signals of 
inflammation onset. It is also known that mammary development is a process with features in common to the inflammation (e.g. edema, rash), and that it is tightly modulated by systemic hormones and local secreted factors like beta-1 integrin, epidermal growth factor receptor, matrix metalloproteinases etc. The possible relationship between these two phenomena (development of mammary gland and inflammation) has not been investigated yet, but it seems intriguing (see also section 4.2).

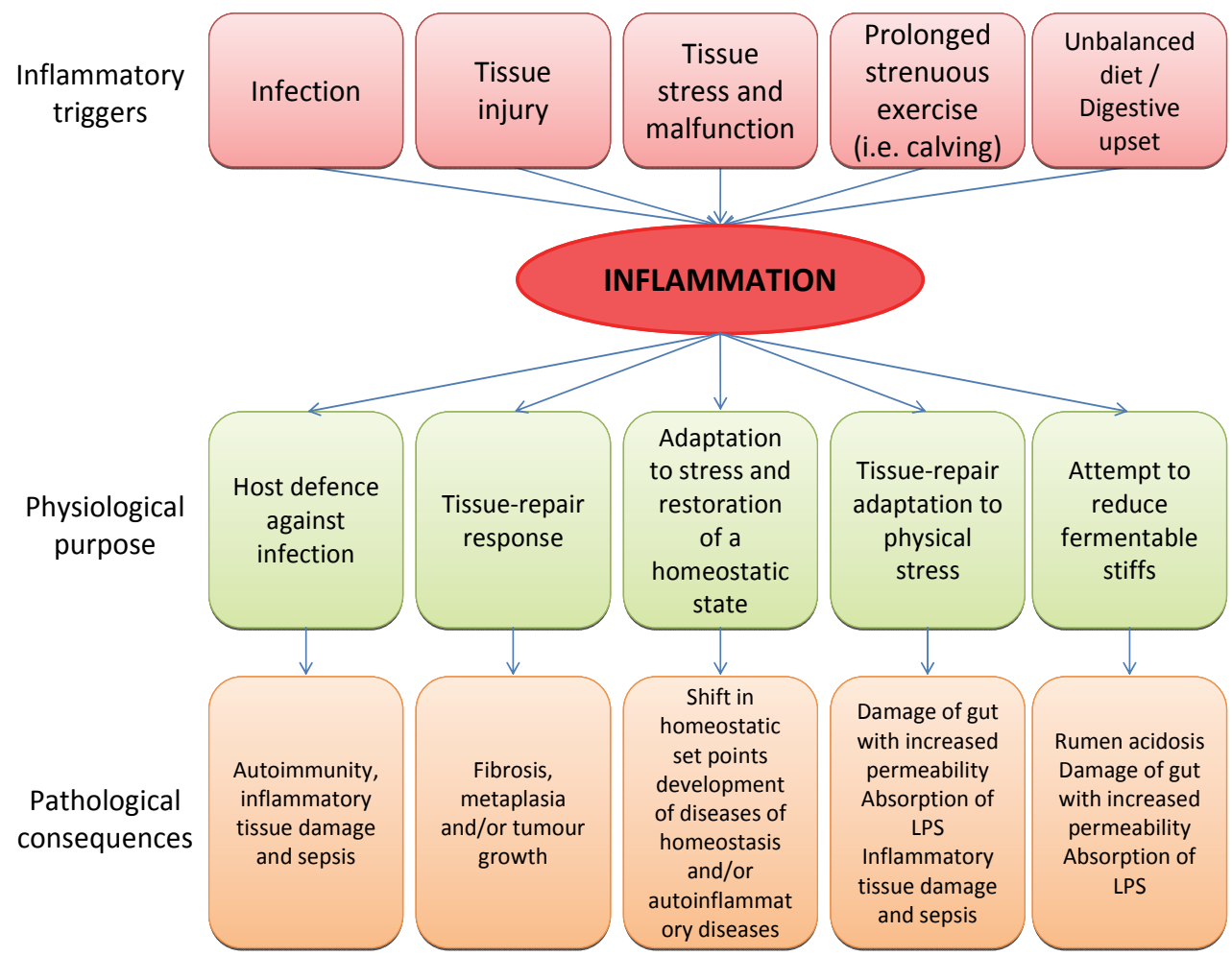

Fig. 1. Cause, physiological and pathological outcomes of inflammation (adapted from Medzhitov, 2008)

\subsubsection{Uterus and placenta}

As previously reported (Trevisi \& Bertoni, 2008), the inflammation is considered a key feature of both preterm and term labour in humans (Lindström \& Bennett, 2005), with an influx of inflammatory cells into the uterus and elevated levels of pro-inflammatory cytokines observed during parturition. Some years before, Simpson et al. (1998) identified a basal production of both pro-inflammatory and anti-inflammatory cytokines at parturition. During its whole life, placenta seems able to produce cytokines to improve its function (Hauguel-de Mouzon \& Guerre-Millo, 2006), and the anti-inflammatory cytokine IL-10 seems important to counteract inflammation associated to preterm parturition (Hanna et al., 2006). Both inflammation and labour seem associated to the activity of NF-kB and thus to the expression of the relevant pro-inflammatory genes, as above reported. 
Interestingly, Sibai et al. (1993) observed that "low-dose aspirin decreases the incidence of preeclampsia among nulliparous women" as possible consequence of lower thromboxane production. This result confirms the possibility to modulate the production of proinflammatory mediators around calving and, therefore, the inflammatory response itself; more research is undoubtedly needed to improve this basic knowledge.

\subsubsection{Physical effort}

Strenuous exercise is accompanied by an increase in circulating proinflammatory and inflammation-responsive cytokines, which shows some similarities with the response to sepsis and trauma as suggested by Pedersen et al. (1998). The same authors observed that sequential release of TNF- $\alpha$, IL-1 $\beta$, IL-6 and IL-1 receptor antagonist (IL-1ra) in the blood is comparable to that observed in relation to bacterial diseases. In particular, Lambert (2009) suggests that prolonged and strenuous exercise, can cause the impairment of intestinal mucosa integrity, increasing its permeability. The exhausting exercise can in fact determine several consequences, like high glucocorticoid levels, reduced blood flow rate, hyperthermia, hypoxia, oxidative and nitrosative stress as well as absorption of lipopolisaccharides, which promote the release of pro-inflammatory cytokines. According to Lambert (2009) data, such intestinal dysfunction is a non-rare condition in pigs. We are not aware of specific data on dairy cows, but prolonged physical activity can occur in case of difficult calving (or dystocia). This physical challenge, accompanied by other disturbances typical of calving time (e.g. trauma, psychological stress, digestive upset, etc.) could induce a release of pro-inflammatory cytokines and, thus, inflammation.

\subsubsection{Infectious diseases linked to immunosuppression}

As previously demonstrated, there exists a strict correlation between the occurrence of infections and a state of substantial immunosuppression in transition dairy cows. Several studies documented impairment of the ability of lymphocytes and neutrophils to respond to infectious challenges in periparturient dairy cows, which is likely to provide an explanation for the high incidence of infections (namely, metritis and environmental mastitis) during the early lactation period (Kehrli et al., 1999; Lacetera et al., 2005; Goff, 2006; Mulligan \& Doherty 2008).

Immunosuppression goes along with marked changes in the endocrine, nutritional and metabolic status that are much more dramatic than at any other time in the life cycle of a dairy cow. The most common causes are:

- increased concentrations of circulating cortisol for several hours around parturition;

- metabolic disturbances [e.g., NEB, hypocalcemia, etc.];

- frequent inadequate feed intake despite an increased energy requirement for the developing conceptus and the impending lactogenesis;

- reduced intake of immunomodulating nutrients (vitamins A and E, selenium, copper and zinc);

- $\quad$ digestive disturbances due to sudden dietary changes;

- $\quad$ oxidative stress with risk of damage for membranes of immune cells;

- environmental stressors deriving from the usual management of dry and lactating dairy cows.

The above events contribute to immunosuppression in the transition period, as shown in previous studies (Grummer, 1995; Burton et al., 2005; Goff, 2006; Spears and Weiss, 2008). 
However, most of them occur at calving time or immediately thereafter. Thus, there are probably further causes of immunosuppression, considering that signs of a disregulated innate immune response start 2-3 weeks before calving.

In this scenario, convincing evidence suggests that periparturient immunosuppression can be partly accounted for by the negative energy balance and related phenomena (e.g. fatty liver syndrome), which act as major contributing factors (Breukink \& Wensing, 1997; Lacetera et al., 2005). Several studies have thus been performed to establish possible causeand-effect relationships between NEB and impairment of the immune response in periparturient dairy ruminants. Recently, Wathes et al. (2009) reported that several inflammatory response genes were upregulated in cows undergoing conditions of severe NEB, whereas Moyes et al. (2010) reported that the majority of genes involved in the acquired immune response were down-regulated in NEB cows. Previous studies indicated that ketotic ruminants are immunosuppressed as well. Also, the hypothesis was tested that immunosuppression under NEB conditions might be due to increased concentration of some metabolites [namely, ketone bodies and nonesterified fatty acids (NEFA)] (Suriyasathaporn et al., 1999; Lacetera et al., 2004). In particular, studies on NEFA indicated that concentrations of plasma NEFA mimicking intense lipomobilization altered (a) the ability of lymphocytes to proliferate or secrete immunoglobulin $M$ and interferon- $\gamma$ in response to polyclonal stimuli (mitogens) (Lacetera et al., 2004), as well as (b) the viability and oxidative burst of polymorphonuclear (PMN) cells (Scalia et al., 2006). Furthermore, some authors recently suggested that plasma concentrations of NEFA may be possible diagnostic markers of impaired immunity and higher risk of infections around parturition (Moyes et al., 2009; Ospina et al., 2010). In particular, Ospina et al (2010) indicated that prepartum and postpartum serum NEFA higher than 0.3 or $0.6 \mathrm{mmol} / \mathrm{l}$, respectively, were associated with increased risk for displaced abomasum, clinical ketosis, retained placenta and metritis.

In addition to that, evidence of a distinct worsening of inflammatory conditions and signs of transient immunosuppression in the periparturient period were consistently detected by the authors in field studies on cohorts of Frisian cattle. Thus, decreased levels of blastogenic response of lymphocytes to mitogens and lower levels of hemolytic complement around parturition went along with APR and altered hematological values, persistent hypoalbuminemia and hyperalphaglobulinemia (see a few results in figure 2). Such a shift from the reference values should be traced back to the peculiar adaptation strategies of these animals to NEB and perhaps to the serious metabolic stress of high-yield lactation.

\subsection{Inflammation and energy balance}

As well known, "Nature has accorded a high priority to the functions of pregnancy and milk secretion, allowing them to proceed at the expense of other metabolic processes even to the point that a disease state is created" (Bauman \& Currie, 1980). Namely, as previously stressed (Bertoni et al., 2009) and except for the case of very serious diseases, milk yield in the first weeks of lactation is pursued much more quickly and independently from feed intake (Figure 3); as a result, NEB is unavoidable. For this reason post-calving cows are characterized by shortage of some metabolic fuels (e.g. glucose and aminoacids), drained by the mammary glands for milk syntheses, and by an increase of metabolites due to lipid mobilization (e.g. NEFA, BHBA). Therefore, what can be avoided is simply an excessive NEB, mainly through a good DMI, because energy concentration cannot be modified to a large extent avoid health disorders. Thus, as suggested by Villa-Godoy et al. (1988), the 
severity of NEB does not seem a consequence of the high milk yield at the beginning of lactation, but a result of poor DMI, which can be caused by diseases (and inflammation) and not only by physical factors.
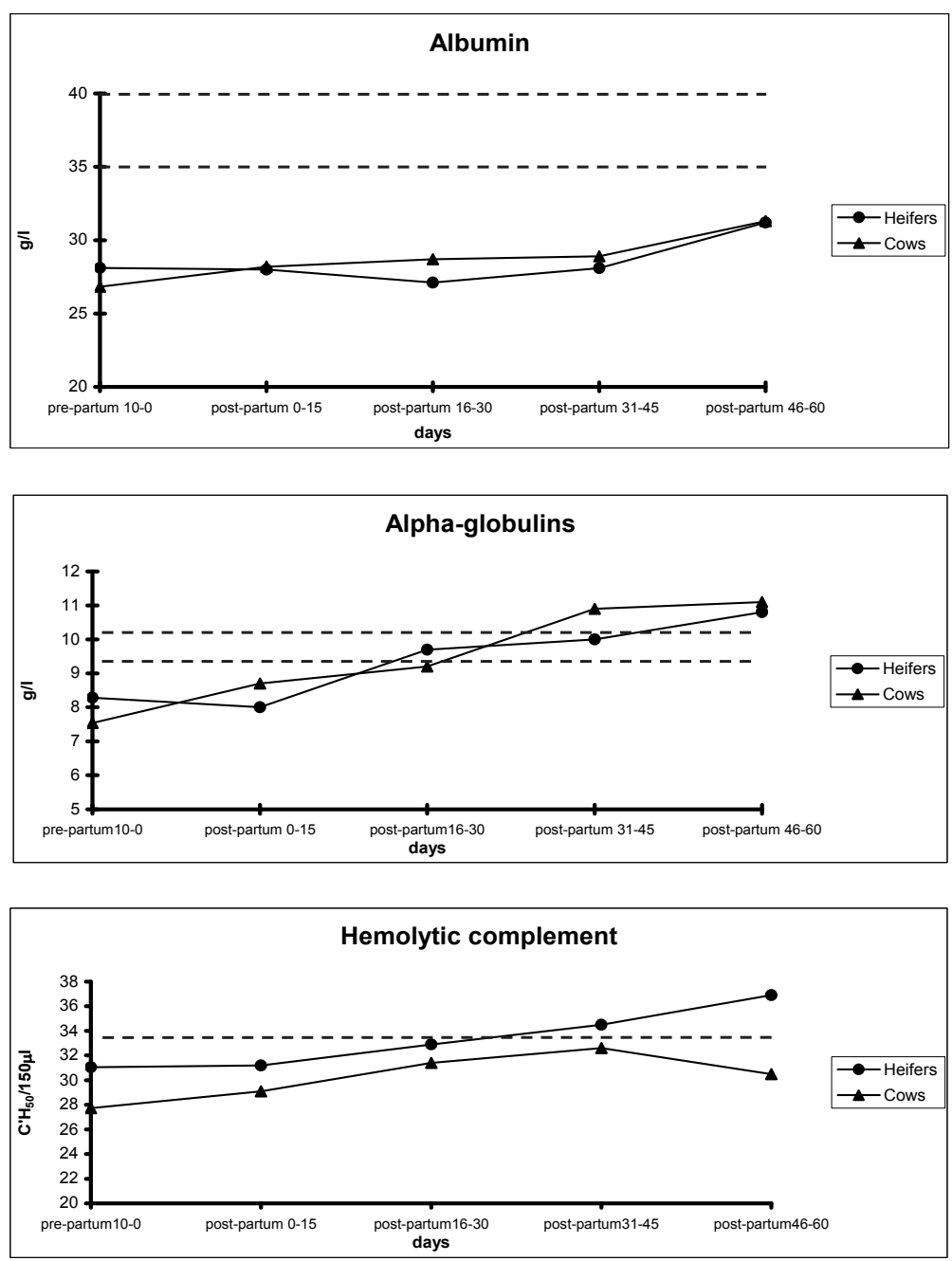

\section{LEGEND}

- - - - limits of normal values. Only the lower one is indicated for hemolytic complement

This study was performed on 30 healthy, high-yielding Italian Frisian dairy cattle (10 heifers and 20 cows), from two herds with a record of very good productive and reproductive performances. Blood samples in vacuum tubes were always collected from the same animals at 10-day intervals from the last two weeks of the dry period until day 60 after parturition. At each time point animals were within a 10day range with respect to the date of parturition. The tests were carried out as previously described (Amadori et al., 1997).

Fig. 2. Time-course of some serum protein fractions and haemolytic complement. 
In general, feed intake is affected by both physical and metabolic factors, but the former appear the limiting ones in early lactation. Nevertheless, in transition cows, other factors could also account for a reduction of DMI. In fact, cows often show marked rises of body temperature $\left(>39.5^{\circ} \mathrm{C}\right)$ in the days following calving. These rises of temperature are mainly consequences of common malaise conditions immediately after parturition, linked to inflammatory phenomena, thus to a release of pro-inflammatory cytokines. As previously suggested, inflammation is also recurrent without disease, because pro-inflammatory mediators, which induce fever as well as anorexia and muscle catabolism (Elsasser et al., 2000), can be released for other causes (figure 1). Unfortunately, NEB is worsened since the metabolic changes induced by cytokines increase the availability of energy for a higher immune system activity. Puigserver et al. (2001) have in fact demonstrated that inflammation is coupled with the increase of cellular respiration and expression of genes linked to mitochondrial uncoupling (e.g. body temperature rise). In accordance with that, cows with more severe inflammation after calving are likely to suffer from a reduced efficiency in the use of Net Energy (Trevisi et al., 2007 and Trevisi et al., 2010); coupled with lower DMI, this means a worsening of usual NEB.

The severe NEB, quite common in early lactating cows, is really dangerous as cause of metabolic diseases (ketosis) and immunosuppression; furthermore it has been associated to a reproductive failure for a negative (toxic) effect on follicles and oocytes (Kruip et al., 1999; Jorritsma et al., 2004).

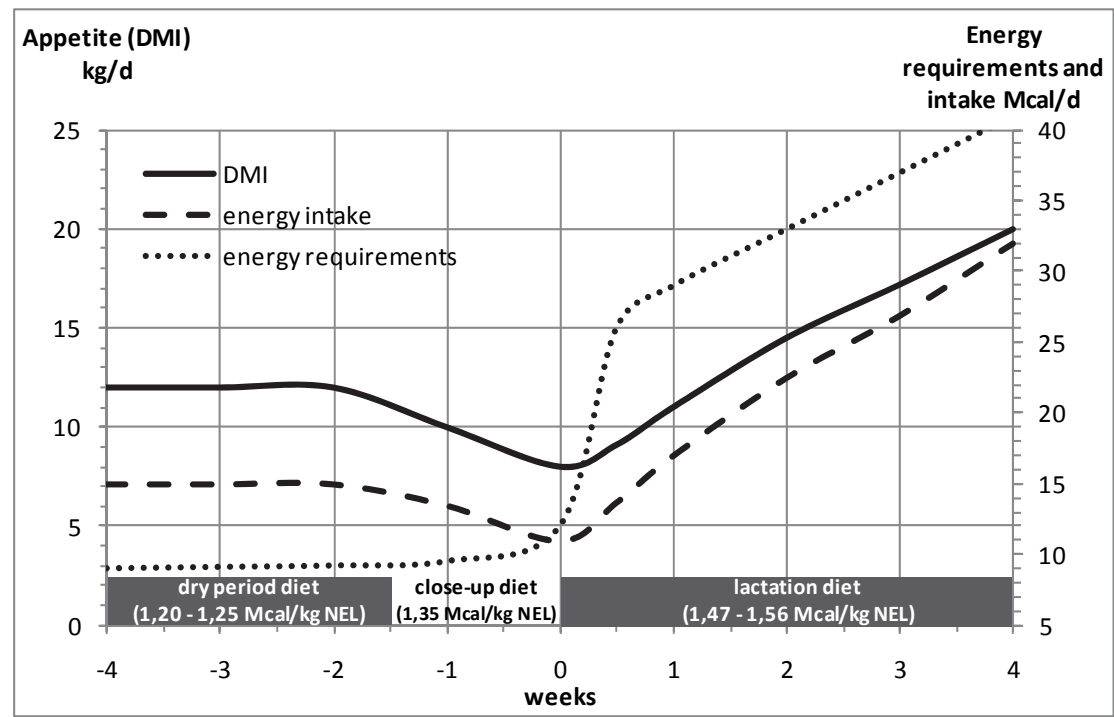

Fig. 3. Average levels of appetite and energy requirements (energy mobilization was not considered) in the transition of high yielding dairy cows. In brackets the suggested net energy for lactation concentrations (NEL) of diets of 3 stages.

\section{Mechanisms of the acute phase response (APR) in the liver}

The negative effect of inflammation at calving time can be also mediated by the liver diversion of activities due to the acute phase response (APR); the increased synthesis of 
haptoglobin and several other positive APP causes a lower synthesis of usual liver proteins, for this reason called negative -APP (albumin, lipoproteins, retinol binding protein etc.).

\subsection{Inflammation and liver changes}

As above explained, some of the inflammation effects - anorexia, catabolic conditions, fever (with an increase in feed energy wastage; Klasing, 2000), adipose mobilization and maybe more the significant disturbance of liver synthesis activity - can be particularly pernicious in the peripartum period. Altogether, they can increase the risk of metabolic diseases, such as ketosis and liver lipidosis, but indirectly of the infectious ones as well (Goff \& Horst, 1997). Looking at liver, pro-inflammatory cytokines promote the liver synthesis of several plasma proteins (Powanda, 1980; Cousins, 1985; Elsasser et al., 1997; Gruys et al., 1999; Murata et al., 2004; Peterson et al., 2004; Gruys et al., 2005) including the positive acute phase proteins (+APP: i.e. haptoglobin, SAA, ceruloplasmin, C-reactive protein, a1-antitrypsin). Unfortunately, this increased synthesis partly competes with the production of the usual liver proteins, which are to some degree reduced at the same time (Fleck, 1989; Wan et al., 1989). Thus, several of these proteins, named the negative APP (-APP), are affected (i.e. albumins, "carriers" of vitamins and hormones, lipoproteins, some specific enzymes as paraoxonase, etc.) (Gruys et al., 2005). The functions of -APP are essential to the metabolic integrity of the animal and their synthesis is therefore highly maintained.

\subsection{Indices to evaluate the consequences of acute phase reactions during the early lactation period}

From the above considerations, -APP seem appropriate indices to detect consequences of an inflammatory condition in the peripartum period. In fact, changes of -APP (e.g. low levels or retarded increases) are prolonged in comparison to the rise of +APP. Moreover, in our experience the association between +APP response after calving and acute inflammatory phenomena is not always very clear and marked. Therefore, we have recently proposed two composed indices based on levels of some-APP observed in the first month of lactation, with the aim to evaluate the changes on liver activity synthesis caused by inflammatory events occurred around caving: the Liver Activity Index (LAI, Trevisi et al., 2001a) and the Liver Functionality Index (LFI; Bertoni et al., 2006).

LAI includes the average blood level at $7^{\text {th }}, 14^{\text {th }}$ and $28^{\text {th }}$ DIM of some proteins synthesized by the liver: albumin, lipoproteins (indirectly measured as total cholesterol), and Retinolbinding Protein (RBP, measured as retinol, as the retinol level in the plasma is strictly related to RBP synthesized by the liver). Data of these 3 blood parameters were transformed into units of standard deviation obtained for each cow as follows: the mean value of the herd population of each plasma parameter (albumin, total cholesterol, and RBP) was subtracted from each cow value at 7, 14, and 28 DIM and divided by the corresponding standard deviation. Thus, the final LAI of each cow is the result of the arithmetical mean of the 3 partial values obtained from the 3 selected blood indices of 3 bleedings. At the end, LAI values represent a good estimation of the consequences of an inflammatory challenge which occurs at calving time, or around it, in each cow checked within a defined herd; therefore, LAI allows to retrospectively rank cows of the same herd from low to good adaptation to some very important risky situations during the transition period.

LFI has the same aim, but includes albumin, lipoproteins (indirectly measured as total cholesterol) and bilirubin (as indirect measure of the enzymes, synthesized by the liver, 
which operate its clearance). LFI is an index of the relevant changes between DIM 3 (V3) and 28 (V28), standardized in accordance with the optimal pattern of changes of the 3 parameters, obtained from healthy cows at the same stage of lactation. For each parameter, LFI calculation is done in 2 steps (table 1). Briefly, the $1^{\text {st }}$ one considers the effects occurred at $3^{\text {rd }}$ DIM (V3) and changes between $3^{\text {rd }}$ and $28^{\text {th }}$ (V28) DIM. For albumin and cholesterol these two effects equally concur $(50 \%)$ to the partial LFI result (Alb-I and Chol-I), while for bilirubin the effect at DIM 3 represents $67 \%$ of the total partial LFI index. In the $2^{\text {nd }}$ step, these partial indices were standardized in accordance with the average values observed in "healthy" cows, as defined by the upper LAI quartiles (Bertoni et al., 2008) (e.g. subtracting the correspondent mean value and dividing by the correspondent standard deviation). Ultimately, LFI was obtained by adding the values of the three partial indices. In table 1 are also included two examples of LFI calculation, belonging to 2 cows, with a low and with a high LFI index.

Respect to LAI, LFI allows to evaluate the same consequences of an inflammatory challenge, occurring at calving time or around it, but the retrospective ranking can include cows belonging to different herds. Anyhow it is interesting that the two indices are well correlated (Trevisi et al., 2010b). Therefore, considering that the determination of LFI is easier and cheaper than LAI, and that LFI allows for a comparison between herds, LFI appears a more reliable index to measure the success/failure of cow adaptation in the transition period.

\begin{tabular}{|c|c|}
\hline Step 1 & Albumin (Alb-I) sub-index $=50 \%$ V3 + 50\% (V28-V3) \\
\hline & $\begin{array}{l}\text { Cholesterol (Chol-I) sub-index }=50 \% \text { V3 }+50 \%(\mathrm{~V} 28-\mathrm{V} 3) \\
\text { Bilirubin (Bil-I) sub-index }=67 \% \text { V3 }+33 \%(\mathrm{~V} 3-\mathrm{V} 28)\end{array}$ \\
\hline Step 2 & LFI $=($ Alb-I $-17,71) / 1,08+($ Chol-I $-2,57) / 0,43-($ Bil-I $-6,08) / 2,17$ \\
\hline
\end{tabular}

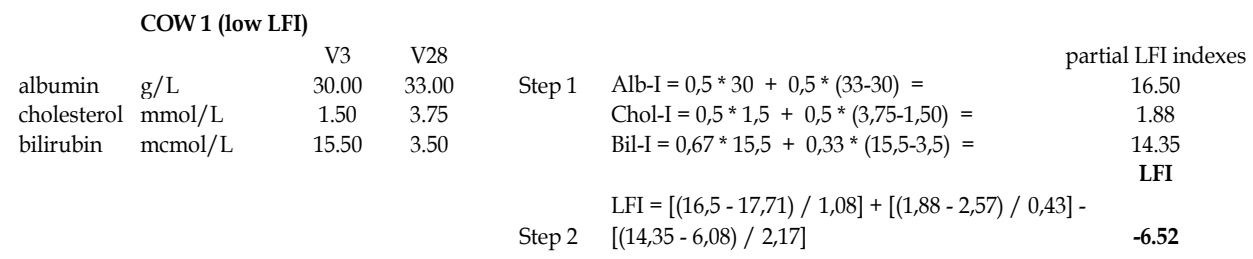

\begin{tabular}{|c|c|c|c|c|c|c|}
\hline & COW 2 (h & & & & & \\
\hline & & V3 & V28 & & & artial LFI indexes \\
\hline albumin & $\mathrm{g} / \mathrm{L}$ & 35.00 & 38.00 & Step 1 & Alb-I $=0,5 * 35+0,5 *(38-35)=$ & 19.00 \\
\hline cholesterol & $\mathrm{mmol} / \mathrm{L}$ & 1.80 & 5.50 & & Chol-I $=0,5 * 1,8+0,5 *(5,5-1,80)=$ & 2.75 \\
\hline bilirubin & $\mathrm{mcmol} / \mathrm{L}$ & 6.00 & 1.50 & & Bil-I $=0,67 * 6,0+0,33 *(8,0-1,5)=$ & 6.17 \\
\hline & & & & & & LFI \\
\hline & & & & Step 2 & $\begin{array}{l}\mathrm{LFI}=[(19,0-17,71) / 1,08]+[(2,75-2,57) / 0,43]- \\
{[(6,17-6,08) / 2,17]}\end{array}$ & 1.57 \\
\hline
\end{tabular}

Table 1. Example of the calculation of LFI index.

\subsubsection{Practical use of LAI and LFI indices}

Inflammatory phenomena at calving time are well related to more severe health problems sometime without strong reduction of milk yield reduction - as well as to the reduction of 
performance and fertility (Bionaz et al., 2007; Bertoni et al., 2008). Therefore, by monitoring LAI or more conveniently LFI, it is possible to identify subjects that need more attention and proper therapies. In fact, these indexes, if determined in all the transition subjects in a herd, measure the extent of inflammatory consequences and are useful to show their presence in cows not affected by clinical symptoms. In accordance with the low LAI and LFI as well as some other indices (clinical, metabolic, productive, BCS, etc.,) we can observe two different types of cows at the end of the first month of lactation:

i. subjects that continue to suffer from inflammatory phenomena, indicated - for example - by high plasma haptoglobin level. These cows require an accurate diagnosis, mainly concerning uterus, mammary gland, foot integrity and functioning, etc.;

ii. subjects that have solved inflammatory events occurred around calving, but maintain inadequate liver function, which demands some support to accelerate liver recovery.

Finally, all the subjects under these conditions are at risk for fertility.

\subsubsection{APR changes with prognostic value}

In any case, in consideration of the adopted procedures both LAI and LFI are not able to detect in advance cows at risk in the peripartum period. Therefore, of remarkable usefulness would be the identification of parameters showing differences in the period that precedes calving, and, therefore, with a predictive meaning at calving time.

Interestingly, by ranking cows at the end of the $1^{\text {st }}$ month of lactation for LAI or LFI values, we detected important changes in some markers before calving. Cows with low LAI (Trevisi et al., 2010c) are characterized - even without any symptom - by slightly lower plasma levels of some -APP (e.g. RBP, lipoprotein, albumin) and haemolytic complement, as well as higher levels of syalic acid and ROMs in the last month of pregnancy. In other experiments (Trevisi et al., 2010a; Trevisi et al., 2010b), cows with lower LFI showed - again before calving and without clinical symptoms - higher levels of IL-6, ceruloplasmin, bilirubin, NEFA, ROM and lower ones of RBP and lysozyme. Most of the differences observed in the latter experiences were marked in comparison to previous research and reached statistical significance. Despite these results are been obtained in cows with extremely low levels of LFI, they confirm what appears in several experiences: animals which previously suffered for inflammations are more responsive to new inflammatory challenges; it is difficult to establish if higher susceptibility is innate or acquired.

In general, these results suggest that before calving we can observe two different conditions:

- $\quad$ subjects that show inflammatory phenomena without clinical symptoms, which could be detected by the rise of +APP (e.g. haptoglobin), pro-inflammatory cytokines (e.g. IL6), lipomobilization (e.g. increase of NEFA) and oxidative stress (e.g. rise of ROM);

- subjects that only present residual signals of previous inflammatory events, which could be detected mainly by the slightly lower levels of some -APP (e.g. lipoprotein, albumin and RBP), but also lysozyme.

In the first case (subclinical inflammations), the approach will be an attempt to identify the possible cause of health disorders (e.g. mastitis, lameness, etc.) with further and detailed investigations, followed by appropriate therapy. In the second case, the subjects should be followed with more attention at calving time because they are likely to be more susceptible to any inflammatory challenge; these animals are eligible for treatments with antiinflammatory molecules (e.g. acetyl-salicylic acid) immediately after parturition. 


\subsection{From APR to a metabolic stress: Causes and effects}

As previously suggested (Figure 1), the APR can take place in the absence of detectable infections even before calving, thus increasing the risk of possible traumas and related tissue damage at calving time. Thus, the observed response does not fit into conventional models of APR, which implies that the origin of such a response should be set into an alternative conceptual framework. In this respect, we have to consider that APR is part of an ancestral, overlapping set of immune, stress and inflammatory responses aimed at the neutralization of stimuli perturbing immune system homeostasis (Ottaviani \& Franceschi, 1998). In this scenario, the effector mechanisms are remarkably similar for both infectious and non-infectious stimuli. In fact, a pro-inflammatory cytokine like IL-1 induces activation of the hypothalamo-pituitary-adrenocortical (HPA) axis as well as stimulation of cerebral noradrenaline; the effects of IL-1 are remarkably similar to those observed following either LPS administration (reminiscent of infectious stress) - that cause the release of proinflammatory cytokines - or acute, non-infectious stressing events in laboratory animals, such as electric shock or restraint (Dunn et al., 1999). Therefore, an innate immune response can be mounted in different forms and extent by the host after exposure to both infectious and non-infectious stimuli.

Not surprisingly, acute inflammation (e.g. cellular damage) also triggers innate immune responses, which are very similar to those observed after an infectious stress. Nevertheless, at ordinary calving cows do not suffer from severe metabolic stress; therefore, this does not seem the cause of inflammatory conditions, but a consequence and a possible amplification factor. On the other hand, compelling evidence shows that some cytokines promote the metabolic stress, on which a potent regulation can be also exerted by orally (e.g. IFN-alpha; Trevisi et al., 2009) or parenterally administered cytokines. Some major findings deserve utmost attention:

- there is an up-regulation of several genes related to metabolic and physiologic functions after oral delivery of human IFN-alpha in cattle (Namangala et al., 2006), which implies a connection with metabolic stress;

- the IL-6 gene plays a crucial homeostatic role in hepatocytes of transition cows during inflammation and ketosis; under these conditions IL-6 can exert important effects on metabolic and energy production pathways, while inducing APR at the same time (Loor et al., 2007).

\subsection{Effector mechanisms of the APR}

Which rational link can be surmised between metabolic stress, inflammatory cytokines and APR? One of the likely associations between metabolic stress and innate immunity could be traced back to the lymphoid stress-surveillance system, i.e. to the network of lymphocyte populations (mainly $\gamma \delta \mathrm{T}$ cells) which recognize neo-antigens like MIC on stressed cells (Hayday A.C., 2009), i.e. cells exposed to events as diverse as heat shock, infections, DNA damage, etc. Also in cattle, MIC proteins are ligands for the activating NK cell receptor NKG2D, expressed on NK cells, CD8+ $\alpha \beta$ T cells and $\gamma \delta ~ T$ cells; stimulation of these cells with recombinant MIC causes an IFN-ү response (Guzman et al., 2010); this is likely to trigger and sustain inflammatory cascades by activating macrophages for a sustained release of ROM and reactive nitrogen intermediates (RNIs) (Schreiber \& Schreiber, 2003).

Levels of oxidative stress are actually increased in the periparturient period, but it often occurs only after calving (Bertoni et al., 2008; Sordillo et al., 2009), as consequences of 
inflammatory conditions that precede metabolic stress. Interestingly, this condition seems more evident in high-yielding dairy cows that are more susceptible to inflammatory events that occur at calving time. In this scenario, major negative outcomes of metabolic performance (oxidative stress, tissue hypoxia, accumulation of toxic metabolites, etc.) could easily give rise to activation of the lymphoid stress-associated surveillance system, thus worsening the inflammation.

On the other hand, an inflammatory response could be directly triggered by both hypoxia and accumulation of ROM in tissues and organs. In particular, by a specific hypoxiainducible transcription factor (HIF-1), hypoxia induces the synthesis of vascular endothelial growth factor (VEGF), which increases the permeability of blood vessels in co-operation with $\mathrm{NO}$ and $\mathrm{CO}$ generated by endothelial nitric oxide synthetase (eNOS); in turn, the activity of HIF-1 is stimulated by IL1- $\beta$, Tumor Necrosis Factor (TNF)- $\alpha$ and NO even under normoxic conditions (see Hellwig-Bürgel et al., 2005 for review). Again these conditions are common after calving, therefore the metabolic stress does not seem the primer of inflammation in the periparturient cows, but it confirms an important role in the worsening and in the reiteration of inflammation at this stage.

Owing to the above, the induction of inflammatory conditions underlying APR in periparturient cows can be accounted for by activation of both lymphoid and myeloid effector cells, with possible complementation / synergisms of the relevant final effects, to be investigated in further studies. In addition, the opening of the calving canal in periparturient cows and the exposure of uterus to contaminating environmental bacteria can account for a short-term APR.

\section{Risk factors underlying high APR in the periparturient period}

A few parameters underlying inadequate homeostatic regulation of the inflammatory / AP responses were revealed in some studies of ours and other authors. These can be conveniently divided into factors underlying the very onset of APR (points 1,2) and its subsequent, abnormal amplification (points 3,4):

1. The prepartum levels of serum lysozyme. These are significantly lower in subjects which develop lower levels of -APP in the first month of lactation (Trevisi et al., manuscript submitted). Interestingly, lysozyme at certain concentrations can exert in vitro a significant down-regulation of IL-8, TNF-alpha and caspase-1 responses (Trevisi et al., manuscript submitted). The lysozyme gene is located on chromosome BTA5 in a region where quantitative trait loci (QTL) for milk production have been mapped. The role of lysozyme in controlling post-partum inflammation makes the lysozyme gene a possible candidate for the QTL effect, since lysozyme can affect animal health and welfare in this delicate period and therefore milk production during the entire lactation.

2. Dehydroepiandrosterone (DHEA). This hormone plays an important role in the regulation of inflammatory cytokines like IL-6, as shown by the aging models in humans (Daynes et al., 1993); a major control of the TNF-alpha response has been described as well (Danenberg et al., 1992). Owing to the above, low levels of such a hormone in the dry period may be conducive to the development of an IL-6 and ceruloplasmin response in this phase, as observed by the authors in previous studies. (Trevisi et al., manuscript submitted).

3. The intra ed extracellular Heat Shock Protein $72 \mathrm{kDa}$ (HSP72) complex. In the authors' experience (Catalani et al., 2010a), the HSP72 response is an important component of 
the adaptation strategy of periparturient dairy cows to negative energy balance and lipomobilization after calving. In a global view, the crucial functions of HSP72 in the control of both TNF-alpha and a fundamental cellular alarmin like High Motility Group Box-1 (HMGB-1) (Tang et al., 2007) are probably the foundation of the strong and long-lasting HSP72 response of cows after calving. Beyond that, the HSP72 response is conducive to induction and differentiation of immuno-regulatory Treg cells $(\mathrm{CD} 4+, \mathrm{CD} 25+)$, aimed at containing and restricting the inflammatory responses of the host (Van Eden et al., 2005). Therefore, a defective HSP72 response could outline a risk condition for cows in the post calving period.

4. Some undefined factors underlying the blast response of lymphocytes to bacterial LPS. In the authors' experience (Catalani et al., 2010b) there is a general tendency to a reduction of the blast response of bovine peripheral blood mononuclear cells (PBMC) to LPS after calving; yet, low and high responders in this assay tend to maintain such a feature on a different scale; most important, high responder cows show the least number of disease cases in first weeks of lactation, with a possible association to Single Nucleotide Polymorphisms (SNPs) of the Toll Like Receptor 4 gene to be verified in a large number of animals (see Catalani et al., 2010b). Interestingly, Treg cells induced by the aforementioned HSP72 complex could play a role in the overall reduction of the blast response to LPS, as also suggested by the significant negative correlation between the two variables.

Interestingly, circumstantial evidence in the authors' labs on thousands of cow serum samples (Table 2) indicated that high-yielding Frisian dairy cows show much lower serum lysozyme contents $(<1 \mu \mathrm{g} / \mathrm{ml})$ compared with other dairy and beef cattle breeds; also, the lower lysozyme contents are correlated in our experience with higher peripheral blood granulocyte counts, lower albumin/globulin ratios and persistent monocytosis (data not shown). In this scenario, the IL-6 response observed in some dairy cattle before and after calving (Trevisi et al., manuscript submitted) can contribute to a functional differentiation of monocytes to macrophages (Chomarat et al., 2000), i.e. cells with a higher pro-inflammatory potential.

\section{Hypotheses and acceptable speculations}

\subsection{The crucial role of the late pregnancy period}

We have already addressed in a previous section the issue of possible prognostic factors in cow pregnancy. This tenet was actually suggested by accumulated evidence, showing that a high and long-lasting APR in the periparturient period stems from a major failure of the cows' homeostatic control circuits. Thus, the combined effects of some genetic and environmental factors before calving should activate the aforementioned lymphoid and myeloid surveillance systems; the observed features of defective homeostatic control of the inflammatory response could contribute all together to high and long-lasting APR after calving, associated to a poor outcome of the transition period. In addition, on the basis of the accumulated data (as explained in section 2.2.2 "APR changes with prognostic value"), the authors believe that a defective homeostatic response takes place first before lactation onset, i.e. before the expected phase of serious metabolic stress. In particular, the time-course of both IL-6 and some APP (e.g. ceruloplasmin for +APP and albumin for -APP) responses indicates that relevant noxae should be searched in the late pregnancy, non-lactating period. In this respect, the aforementioned early risk factors for APR occurrence (lysozyme, 


\begin{tabular}{|c|c|c|c|}
\hline & $\begin{array}{l}\text { Albumin } \\
(\mathrm{mg} / \mathrm{ml})\end{array}$ & $\begin{array}{l}\text { Lysozyme } \\
(\mu \mathrm{g} / \mathrm{ml})\end{array}$ & $\begin{array}{c}\text { Haptoglobin } \\
\text { (mg/dL HbBC) }\end{array}$ \\
\hline \multicolumn{4}{|l|}{ Beef cattle (all) } \\
\hline Average & 30.27 & 2.28 & 10.25 \\
\hline Standard deviation & 3.69 & 2.40 & 13.17 \\
\hline $\mathrm{n}$ & 459 & 465 & 465 \\
\hline \multicolumn{4}{|l|}{ Male dairy cattle * } \\
\hline Average & 29.94 & 1.47 & 7.84 \\
\hline Standard deviation & 3.08 & 1.31 & 8.91 \\
\hline $\mathrm{n}$ & 24 & 24 & 24 \\
\hline \multicolumn{4}{|l|}{$\begin{array}{l}\text { Cattle with haptoglobin > } \\
100 \mathrm{mg} / \mathrm{dL} \mathrm{HbBC} * *\end{array}$} \\
\hline Average & 26.52 & 1.70 & 146.20 \\
\hline Standard deviation & 3.74 & 1.60 & 41.15 \\
\hline $\mathrm{n}$ & 7 & 7 & 7 \\
\hline \multicolumn{4}{|l|}{ Beef cattle $<350 \mathrm{KG}$} \\
\hline Average & 28.34 & 2.07 & 12.20 \\
\hline Standard deviation & 4.29 & 1.66 & 13.51 \\
\hline $\mathrm{n}$ & 62 & 63 & 63 \\
\hline \multicolumn{4}{|l|}{ Beef cattle 350-500 KG } \\
\hline Average & 30.12 & 2.44 & 10.94 \\
\hline Standard deviation & 3.41 & 2.70 & 14.79 \\
\hline $\mathrm{n}$ & 262 & 263 & 263 \\
\hline \multicolumn{4}{|l|}{ Beef cattle $>500 \mathrm{KG}$} \\
\hline Average & 30.69 & 2.05 & 9.29 \\
\hline Standard deviation & 3.60 & 1.93 & 9.86 \\
\hline $\mathrm{n}$ & 99 & 99 & 99 \\
\hline
\end{tabular}

* 18 Frisian and 6 Brown cattle $<3$ years old

** Cattle with high haptoglobin serum levels were set apart to illustrate the correlation with low albumin concentrations (negative APR)

Total protein was assessed by the biuret reagent on a Synchron CX5 multi-analyzer (Beckman-Coulter). Serum albumin was determined by electrophoresis on an agarose gel and densitometric examination of protein bands (Hydrasis apparatus, SEBIA). Reference value for adult healthy cattle: $30-35 \mathrm{mg} / \mathrm{ml}$. Haptoglobin was investigated as previously described (Makimura \& Suzuki, 1982). Reference value for healthy cattle: $<10 \mathrm{mg} / \mathrm{dL}$ of Haemoglobin Binding Capacity (HbBC).

Serum lysozyme concentration was measured by the lyso-plate-assay (Osserman \& Lawlor, 1966).

Reference values for healthy cattle: $1-3 \mu \mathrm{g} / \mathrm{ml}$.

Table 2. Clinical chemistry values of beef and non-lactating dairy cattle. 
DHEA) could play a role vis-à-vis a physiological pro-inflammatory stimulation before calving. In turn, the ensuing, disregulated inflammatory conditions in the late pregnancy period could pave the way to high APR and related incidence of disease cases after calving, as indirectly shown ex iuvantibus by the good results of oral acetylsalicylic acid treatments after calving (Bertoni et al., 2004; Trevisi \& Bertoni, 2008). Also, a seriousinflammatory condition of peri-parturient dairy cows is related to a lesser production performance (Bertoni et al., 2008), as repeatedly confirmed in our experience by the lower daily milk yields of cows with ongoing APR under conditions of controlled dry matter uptake.

\subsection{Physiological events in late pregnancy and APR}

Which kind of event could actually trigger an inflammatory response way before stressing events like mammary gland edema, placenta expulsion, calving and lactation onset? The first possibility is obviously represented by subclinical infections, which go undetected by stockmen and practitioners. In particular, reference is made to mastitis cases of the "dry" period, leading to infected mammary gland quarters at lactation onset (Bradley \& Green, 2000; Green et al., 2002). Subclinical viral infections due to poor or no vaccine prophylaxis, as well as neglected podal lesions could undoubtedly play a role, too. However, whenever subclinical microbial infections can be reasonably ruled out, which otherwise innocuous, physiological, pro-inflammatory condition can trigger in some individuals IL-6 and acute phase responses because of poor homeostatic control? A strong case can be probably made for a contribution of the massive leukocyte infiltration into the mammary gland at this stage, aimed at removal of apoptotic cells and cell debris (Oliver \& Sordillo, 1989). In fact, the process of active involution is most likely completed by 21 days after cessation of milking; later on, during steady state involution, fluid volume is maintained at very low levels with the highest concentrations of both macrophages and granulocytes; at this stage, the activity of phagocytic cells is no more compromised like in early involution because of the attempt to eliminate milk components and cellular debris (Nickerson, 1989). As a result, the observed IL-6 and APR in the "dry" period may be coincident with the highest proinflammatory potential of leukocytes infiltrating the mammary gland. Also, as described in a previous chapter, inflammation underlies both preterm and term labour, with an elevated levels of pro-inflammatory cytokines during parturition (Lindström \& Bennett, 2005). Finally, inflammatory stimuli in the central nervous system can induce cytokines in the periphery by increasing sympathetic outflow; this has been demonstrated for IL-6 as well (Johnson, 1997), and it may hold true for the IL-6 response in cattle both before and after calving. Regardless of the triggering event, the authors believe that a primary, disregulated inflammatory response $4-5$ weeks before calving is likely to determine sort of negative imprinting of the innate immune response; in turn, the latter is going to trigger after calving a high and long-lasting APR to the physiological, combined stimuli of calving and exposure of uterus to contaminating environmental bacteria. As explained in the previous paragraphs, such an APR after calving is strongly predictive of disease occurrence and early removal from the herd, this latter feature being obviously affected by the actual precocity of clinical diagnosis and pharmacological treatments.

\subsection{Management of the periparturient period}

It is a strategic period as well known, but its importance may be even greater in highyielding cows which appear more susceptible to inflammation (Table 3). 
1. Ensure proper body condition at dry off and during dry period to provide reserve energy to meet requirements for milk production and reproduction in early lactation, but avoiding any excess: ideal BCS 3.0-3.3 points (Edmonson et al., 1989).

2. Prevent new intramammary infections by proper dry-off procedure: e.g. by combining the usual antibiotic treatment in mammary gland with an intramuscular antibiotic treatment, with a large-spectrum to have also a systemic coverage against bacteria;

3. Prevent virus and bacteria infections: vaccination against main viruses (IBR, BVD, PI3, rota-coronaviruses, E. coli, leptospira) and perhaps antiparasite treatments around dry-off period;

4. Prevent hoof problems: to ensure hoof care (trimming) around dry-off period (within 10 days before or after dry-off)

5. Prevent digestive upsets: proper diet distribution; proper diet composition during the whole dry period to cover energy (about $1.3 \mathrm{Mcal} / \mathrm{kg}$ dry matter as Net Energy), vitamin and mineral requirements and to guarantee about $12 \%$ of crude protein in dry matter; a very short (8-10 d) and light close-up period (addition of about 1.5-2.0 $\mathrm{kg} / \mathrm{d}$ of cereals or lactation concentrate to usual TMR);

6. Ensure comfortable housing: appropriate size of free-stall cubicles, clean and dry pen, thermo neutral conditions, no overcrowding; reduced changes of groups etc.;

7. Proper feeding and housing will prevent any kind of metabolic diseases that however must be quickly treated;

8. Well monitored calving: without hurry and possibly trauma and avoiding isolation;

9. Frequent checks before and after calving to verify health status: rectal temperature, gynaecological visit, good rumen fill, normal utilization of stored fat, high milk production;

10. Stimulate and maintain aggressive appetite during the dry period and early lactation (by specific supplements, if needed).

Table 3. Decalogue of correct dry period and calving management in dairy cows (to reduce inflammatory conditions)

\section{Conclusions}

Our results suggest that any cow in the transition period can incur in inflammatory phenomena of different seriousness and quite often without clinical symptoms. The consequences of this are a worsening of negative energy balance either for a lower dry matter intake and for some waste of energy and nutrients; furthermore, the acute phase response causes a deviation of liver synthesis and in turn a reduction of several proteinenzymes which are responsible for liver functions. The inflammation phenomenon is triggered by pro-inflammatory cytokines as well as by eicosanoids; their release can occur for many different reasons: infections, tissue damage, stress conditions, heavy physical effort, etc.. This means that several and quite different can be the causes of inflammation, so that several have to be the ways to prevent it: infectious and metabolic disease control, reduction of distocya as risk of tissue damage and physical effort, reduction of stress factors (heat, poor housing, digestive disorders which allow the absorption of endotoxins etc.); specific rules for the dry and transition periods should be established and aimed at avoiding or reducing inflammatory conditions around calving. 
From a practical point of view, the consequences of inflammation at calving time are reduction of performance: milk yield, BCS, fertility, but also an increased risk of new diseases for an impairment of the immune system and liver functions (also due to higher fat lipidosis). Worthwhile could be the possibility to detect - before calving - at risk animals which could be treated to reduce the inflammation consequences (i.e. by acetylsalicylate immediately after calving); also useful could be the possibility to recognize in early lactation the cows which suffered for severe and prolonged inflammations with different levels of seriousness after calving. These latter cows could be in fact treated to stop inflammation, to promote liver recovery and to improve the reproductive activity. Blood samples 2-3 weeks before calving or immediately after it and at the end of $1^{\text {st }}$ month of lactation can allow for prediction of these situations, in accordance with the acute phase protein changes.

\section{Acknowledgements}

The co-operation of Dr. L. Bertocchi and Dr. G. Tadeo (IZSLER, Brescia, Italy) and Dr. F. Piccioli-Cappelli, Dr. P. Grossi and Dr. S. Cogrossi (Istituto di Zootecnica, Università Cattolica S. Cuore, Piacenza, Italy) in field surveys on cattle is gratefully acknowledged. This study was financially co-supported by the Italian Ministry of Health (Project IZSLER PRF 2006201) and Università Cattolica del S. Cuore.

\section{References}

Amadori, M., Archetti, I.L., Frasnelli, M., Bagni, M., Olzi, E., Caronno, G. \& Lanteri, M. (1997). An immunological approach to the evaluation of welfare in Holstein Frisian cattle. Journal of Veterinary Medicine Series B, Vol. 44, pp. 321-327, ISSN 0514-7166.

Bauman, D.E. \& Currie, W.B. (1980). Partitioning of nutrients during pregnancy and lactation: a review of mechanisms involving homeostasis and homeorhesis. Journal of Dairy Science, 63: 1514-1529, ISSN: 0022-0302

Bertoni, G., Calamari, L., Maianti, M.G. \& Cappa, V. (1997). Factors others then milk yield that affect the reproductive traits of dairy cows. Livestock Production Science (1997) 50, 99-100, ISSN 1871-1413

Bertoni, G., Trevisi, E. \& Librandi, F. (2003). Treatments with antibiotics or with AntiEndotoxin serum before calving: effects on milk yield and fertility. XV Congresso Nazionale A.S.P.A., Parma, 18-20 giugno 2003. Italian Journal of Animal Science, vol. 2 (suppl. 1): 163-165, ISBN 88-86817-02-9

Bertoni G., Trevisi, E. \& Piccioli-Cappelli, F. (2004). Effects of Acetyl-salycilate used in postcalving of dairy cows. Veterinay. Research Communication 28 (Suppl.1):217-219, ISSN: 0165-7380

Bertoni, G., Trevisi, E., Ferrari, A.R. \& Gubbiotti, A. (2006). The dairy cow performances can be affected by inflammations occurring around calving. Book of Abstract of the 57th EAAP Meeting, 17-20 September 2006, Antalya, Turkey, 325, ISBN: 978-90-8686-0036

Bertoni, G., Trevisi, E., Han, X. \& Bionaz, M. (2008). Effects of Inflammatory Conditions on Liver Activity in the Puerperium and Consequences for Performance in Dairy Cows. Journal of Dairy Science, 91:3300-3310, ISSN 0022-0302 
Bertoni, G., Trevisi, E. \& Lombardelli, R. (2009). Some new aspects of nutrition, health conditions and fertility of intensively reared dairy cows. Italian Journal of Animal Science, vol. 8, 491-518, 2009, ISSN: 15944077

Bionaz, M., Trevisi, E., Calamari, L., Librandi, F., Ferrari, A. \& Bertoni, G. (2007). Plasma Paraoxonase, Health Problems, Inflammatory Conditions and Liver Function in Transition Dairy Cows. Journal of Dairy Science 90:1740-1750, ISSN: 0022-0302

Bradley, A.J. \& Green, M.J. (2000). A Study of the Incidence and Significance of Intramammary Enterobacterial Infections Acquired During the Dry Period. Journal of Dairy Science 83:1957-1965, ISSN 0022-0302.

Breukink, H.J \& Wensing, T. (1997). Pathophysiology of the liver in high yielding dairy cows and its consequences for health and production. Israel Journal of Veterinary Medicine, 52, pp. 66-72. ISSN: 0334-9152

Burton, J.L., Madesn, S.A., Chang, L.-C, Weber, P.S.D., Buckham, K.R., R.van Dorp, Hickey, M.-C. \& Earley, B. (2005). Gene expression signatures in neutrophils exposed to glucocorticoids: a new paradigm to help explain 'neutrophil dysfunction' in periparturient dairy cows. Veterinary. Immunology and Immunopathology, 105, pp. 197-219, ISSN: 0165-2427

Calamari, L., Maianti, M.G. \& Bertoni, G. (1997) - Relazioni fra potenzialità produttiva, problemi nel puerperio e fertilità nella vacca da latte. $9^{\circ}$ Meeting Nazionale "Studio dell'efficienza riproduttiva degli animali di interesse zootecnico", Bergamo, 16 maggio 1997: 99-103.

Cappa, V., Trevisi, E. \& Bertoni, G. (1989). Variazioni ematiche e produttive nel $1^{\circ}$ mese di lattazione in bovine di allevamenti con o senza problemi "post-partum". Zootecnica e Nutrizione Animale, 15: 645-660, ISSN: 0390-0487

Catalani, E., Amadori, M., Vitali, A., Bernabucci, U., Nardone, A. \& Lacetera, N. (2010a). The Hsp72 response in peri-parturient dairy cows: relationships with metabolic and immunological parameters. Cell Stress and Chaperones, Vol. 15, pp. 781-790, ISSN 1355-8145.

Catalani, E., Amadori, M., Vitali, A., Nardone, A., Bernabucci, U.\& Lacetera, N. (2010b). Relationships between lipopolysaccharide responsiveness, genetic characteristics and incidence of infections in peri-parturient dairy cows. Proceedings 9th International Veterinary Immunology Symposium (IVIS), Tokyo. Japan, August 16-20, Pp. 138 (abs.).

Chomarat, P., Banchereau, J., Davoust, J. \& Palucka, A.K. (2000). IL-6 switches the differentiation of monocytes from dendritic cells to macrophages. Nature immunology, Vol. 1, pp. 510-514, ISSN 1529-2908.

Cousins, R.J. (1985). Absorption, transport and hepatic metabolism of copper and zinc: special reference to metallothionein and ceruloplasmin. Physiological Review, 65(2): 238-309, ISSN: 0031-9333

Danenberg, H.D., Alpert, G., Lustig, S. \& Ben-Nathan, D. (1992). Dehydroepiandrosterone protects mice from endotoxin toxicity and reduces tumor necrosis factor production. Antimicrobial agents and chemotherapy, Vol. 36, pp. 2275-2279, ISSN 00664804 . 
Daynes, R.A., Araneo, B.A., Ershler, W.B., Maloney, C., Li, G.Z. \& Ryu, S.Y. (1993). Altered regulation of IL-6 production with normal aging. Possible linkage to the ageassociated decline in dehydroepiandrosterone and its sulfated derivative. Journal of immunology, Vol. 150, pp. 5219-5230, ISSN 0022-1767.

Dinarello, C.A. (1997). Proinflammatory and anti-inflammatory cytokines as mediators in the pathogenesis of septic shock. Chest, 112:321S-329S, ISSN: 0012-3692

Drackley, J.K. (1999). Biology of dairy cows during the transition period: the final frontier? Journal of Dairy Science, 82: 2259-2273, ISSN: 0022-0302

Drackley, J.K., Dann, H.M., Douglas, G.N., Guretzky, N.A., Litherland, N.B., Underwood, J.P. \& Loor, J.J. (2005). Physiological and pathological adaptations in dairy cows that may increase susceptibility to periparturient diseases and disorders. Italian Journal of Animal Science 4:323-344, ISSN: 15944077

Dunn, A.J., Wang, J. \& Ando, T. (1999). Effects of cytokines on cerebral neurotransmission. Comparison with the effects of stress. Advances in Experimental Medicine and Biology, Vol. 461, pp. 117-127, ISSN 0065-2598.

Elewaut, D., Didonato, J.A., Kim, J.M., O'Neill, D., Truong, F., Eckmann, L. \& Kagnoff, M.F. (1999). Nuclear factor-kappa B is a central regulator of the intestinal epithelial cell innate immune response induced by infection with enteroinvasive bacteria. Journal of Immunology, 163:1457-1466, ISSN: 0022-1767

Elsasser, T.H., Kahl, S., Steele, N.C. \& Rumsey, T.S. (1997). Nutritional modulation of somatotropic axis-cytokine relationships in cattle: a brief review. Comparative biochemistry and physiology, 116A(3): 209-221, ISSN: 0300-9629

Elsasser, T.H., Klasing, K.C., Filipov, N. \& Thompson, F. (2000). The metabolic consequences of stress: targets for stress and priorities of nutrient use. In: The biology of animal stress. Basic principles and implications for animals welfare, edited by G.P. Moberg and J.A Mench, CABI Publishing. Pages 77-110, ISBN 978-0851993591

Erb, H.N. \& Grohn, Y.T. (1988). Epidemiology of metabolic disorders in the periparturient dairy cows. Journal of Dairy Science. 71:2556-2571, ISSN: 0022-0302

Fleck, A. (1989). Clinical and nutritional aspects of changes in acute phase proteins during inflammation. Proceedings of the Nutrition Society, 48: 347-354, ISSN: 0029-6651

Goff, J.P. (2006). Major advances in our understanding of nutritional influences on bovine health. Journal of Dairy Science, 89, 1292-1301. ISSN: 0022-0302

Goff, J.P., Horst, R.L. (1997). Physiological changes at parturition and their relationship to metabolic disorders. Journal of Dairy Science, 80:1260-1268. ISSN: 0022-0302

Green, M.J., Green, L.E., Medley G.F., Schukken Y.H. \& Bradley A.J. (2002). Influence of Dry Period Bacterial Intramammary Infection on Clinical Mastitis in Dairy Cows. Journal of Dairy Science, 85:2589-2599, ISSN: 0022-0302

Grimble, R.F. (2001). Stress proteins in disease: metabolism on a knife edge. Clinical Nutrition, 20(6): 469-476, ISSN: 0261-5614

Grummer, R.R. (1995). Impact of changes in organic nutrient metabolism on feeding the transition cow. Journal of Animal Science 73, pp. 2820-2833, ISSN: 0021-8812

Gruys, E., Toussaint, M.J., Landman, W.J., Tivapasi, M., Chamanza, R. \& VanVeen, L. (1999). Infection, inflammation and stress inhibit growth. Mechanisms and non-specific 
assessment of the processes by acute phase proteins. In: Production diseases in farm animals, edited by Th. Wensing, Wageningen Pers, 72-87, ISBN 9789076998572

Gruys, E., Toussaint, M.J., Niewold, T.A. \& Koopmans, S.J. (2005). Acute phase reaction and acute phase proteins. Journal of Zhejiang University-SCIENCE B (Biomedicine $\mathcal{E}$ Biotechnology)., 6(11):1045-1056, ISSNs 1673-565X

Guzman, E., Birch, J.R. \& Ellis S.A. (2010). Cattle MIC is a ligand for the activating NK cell receptor NKG2D. Veterinary Immunology and Immunopathology, Vol. 136, pp. 227234. doi: 10.1016/j.vetimm.2010.03.012, ISSN 0165-2427.

Hauguel-de Mouzon, S. \& Guerre-Millo, M. (2006). The placenta cytokine network and inflammatory signals. Placenta, 27:794-798, ISSN: 0143-4004

Hanna, N., Bonifacio, L., Weinberger, B., Reddy, P., Murphy, P., Romero, R. \& Sharma S. (2006). Evidence for interleukin-10-mediated inhibition of cyclooxygenase-2 expression and prostaglandin production in preterm human placenta. American Journal of Reproductive Immunology, 55: 19-27, ISSN:1600-0897

Hayday, A.C. (2009). $\gamma \delta \mathrm{T}$ cells and the lymphoid stress-surveillance response. Immunity, Vol. 31, No. 2, (August 2009), pp 184-196, ISSN 1074-7613.

Hellwig-Bürger, T., Stiehl, D.P., Wagner, A.E., Metzen, E. \& Jelkmann, W. (2005). HypoxiaInducible Factor-1 (HIF-1): a novel transcription factor in immune reactions. Journal of Interferon \& Cytokine Research, Vol. 25, pp. 297-310, ISSN 1079-9907.

Johnson, R.W. (1997). Inhibition of growth by pro-inflammatory cytokines: an integrated view. Journal of Animal Science, Vol. 75, pp. 1244-1255, ISSN 0021-8812.

Jorritsma, R., César, M.L., Hermans, J.T., Krintwagen, C.L.J.J., Vos, P.L.A.M. \& Kruip, T.A.M. (2004). Effects of non-esterified fatty acids on bovine granulosa cells and developmental potential of oocytes in vitro. Animal Reproduction Science 81:225-235, ISSN: 0378-4320

Kapcala, P.L. (1999). Inflammatory stress and the immune system. In "Military strategies for sustainment of nutrition and immune function and Immune Function", National Academy Press, Washington, D.C., pp. 409-436, ISBN 9780309063456

Kehrli, M.E. Jr., Kimura, K., Goff, J.P., Stabel, J.R. \& Nonnecke, B.J. (1999). Immunological dysfunction in periparturient cows - What role does it play in postpartum infectious diseases? Proc. Annu. Conf. Am. Assoc. Bovine Pract., pp. 24-28. ISSN: 00951137

Klasing, K.C. (2000). Dietary approaches to protecting animal health. In: "Agenda 2000: the food revolution", Alltech's European ed., Nicholasville, KY, USA, pp 9-19.

Kruip, T.A.M., Meijer, G.A., Rukkwamsuk, T. \& Wensing, T. (1999). Investigation into the mechanisms of reduction in fertility of high yielding cows. In: Th. Wensing (ed.) Production diseases in farm animals. Wageningen Pers, Wageningen, The Netherlands, pp 183-190, ISBN 90-74134-60-2

Lacetera, N., Scalia, D., Franci, O., Bernabucci, U., Ronchi, B. \& Nardone, A. (2004). Effects of nonesterified fatty acids on lymphocyte functions in dairy heifers. Journal of Dairy Science 87, pp.1012-1014. ISSN: 0022-0302

Lacetera, N., Scalia, D., Bernabucci, U., Ronchi, B., Pirazzi, D. \& Nardone, A. (2005). Lymphocyte functions in overconditioned cows around parturition. Journal of Dairy Science 88, pp. 2010-2016. ISSN: 0022-0302 
Lambert, G.P. (2009). Stress-induced gastrointestinal barrier dysfunction and its inflammatory effects. Journal of Animal Science, 87(E. Suppl.):E101-E108, ISSN: 00218812

Lindström, T.M. \& Bennett P.R. (2005). The role of nuclear factor kappa B in human labour. Reproduction 130: 569-581, ISSN: 1470-1626

Loor, J.J., Everts, R.E., Bionaz, M., Dann, H.M., Morin, D.E., Oliveira, R., Rodriguez-Zas, S.L., Drackley, J.K. \& Lewin, H.A. (2007). Nutrition-induced ketosis alters metabolic and signaling gene networks in liver of periparturient dairy cows. Physiological Genomics, Vol. 32, pp. 105-116, ISSN 1094-8341.

Medzhitov, R. (2008). Origin and physiological roles of inflammation. Nature, vol. 454, pp. 428-435. ISSN 0028-0836

Moyes, K.M., Larsen, T., Friggens, N.C., Drackley, J.K., \& Ingvartsen, K.L. (2009). Identification of potential markers in blood for the development of subclinical and clinical mastitis in dairy cattle at parturition and during early lactation. Journal of Dairy Science 92, pp. 5419-5428. ISSN: 0022-0302

Moyes, K.M., Drackley, J.K., Morin, D.E., Rodriguez-Zas, S.L., Everts.3, R.E., Lewin, H.A. \& Loor, J.J. (2010). Mammary gene expression profiles during an intramammary challenge reveal potential mechanisms linking negative energy balance with impaired immune response. Physioogical Genomics 41, pp. 161-170. ISSN: 1094-8341

Müller-Decker, K. (1999). Ciclooxygenases. In "Prostaglandins, Leukotriens and other eicosanoids" Eds. Marks F., Fürstenberger, Wiley-VCH, Germany. Pages 65-88, ISBN 3-527-29360-4

Mulligan, F.J. \& Doherty, M.L. (2008). Production diseases of the transition cow. Veterinary Journal 176, pp. 3-9. ISSN: 1090-0233

Murata, H., Shimada, N. 6 Yoshioka M. (2004). Current research on acute phase proteins in veterinary diagnosis: an overview. Veterinary Journal, 168:28-40, ISSN: 1090-0233

Namangala, B., Inoue, N., Kohara, J., Kuboki, N., Sakurai, T., Hayashida, K. \& Sugimoto, C. (2006). Evidence for the immunostimulatory effects of low-dose orally delivered human IFN-alpha in cattle. Journal of Interferon $\mathcal{E}$ Cytokine Research, Vol. 26, pp. 675681, ISSN 1079-9907.

Nickerson, S.C. (1989). Immunological aspects of mammary involution. Journal of Dairy Science, Vol. 72, No. 6, pp. 1665-1678, ISSN 0022-0302.

Oliver, S.P. \& Sordillo L.M. (1989). Approaches to the manipulation of mammary involution. Journal of Dairy Science, Vol. 72, No. 6, pp. 1647-1664, ISSN 0022-0302.

Ospina, P.A., Nydam, D.V., Stokol, T. \& Overton, T.R. (2010). Evaluation of nonesterified fatty acids and $\beta$-hydroxybutyrate in transition dairy cattle in the northeastern United States: Critical thresholds for prediction of clinical diseases. Journal of Dairy Science 93, pp. 546-554. ISSN: 0022-0302

Ottaviani, E. \& Franceschi, C. (1998). A new theory on the common evolutionary origin of natural immunity, inflammation and stress response: the invertebrate phagocytic immunocyte as an eye-witness. Domestic Animal Endocrinology, Vol. 15, pp. 291296, ISSN 0739-7240. 
Pedersen, B.K., Ostrowski, K., Rohde, T., Bruunsgaard, H. (1998). The cytokine response to strenuous exercise. Canadian Journal of Physiology and Pharmacology 76(5): 505-511. doi:10.1139/cjpp-76-5-505. ISSN 0008-4212

Petersen, H.H., Nielsen, J.P. \& Heegaard, P.M. (2004). Application of acute phase protein measurements in veterinary clinical chemistry. Veterinary Research, 35: 163-187, ISSN 0928-4249

Pond, C.M. \& Newsholme, E.A. (1999). Coping with metabolic stress in wild and domesticated animals. In: Oldham, J.D., Simm, G., Groen, A.F., Nielsen, B.L., Pryce, J.E., Lawrence, T.L.J. (Eds.), “Metabolic Stress in Dairy Cows”, Vol. 24. British Society of Animal Science, pp. 9 - 20, Occasional publication.

Powanda, M.C. (1980). Host metabolic alterations during inflammatory stress as related to nutritional status. American Journal of Veterinary Research, 41(11): 1905-1911, ISSN:0002-9645

Puigserver, P., Rhee, J., Lin, J., Wu, Z., Yoon, J.C., Zhang, C-Y., Krauss, S., Mootha, V. K., Lowell, B.B. \& Spiegelman, B.M. (2001). Cytokine stimulation of energy expenditure through p38 MAP kinase activation of PPARg coactivator-1. Molecular cell, 8(5):971-982, ISSN:1097-2765

Richards, C.D. \& Gauldie, J. (1995). Role of Cytokines in acute-phase response. In "Human Cytokines: Their Role in Disease and Therapy", edited by Aggarwal B.B. and Puri K.R., Blackwell Science, Cambridge (USA). Pages 253-263 ISBN 9780865423527

Rowlands, B.J. \& Gardiner, K.R. (1998). Nutritional modulation of gut inflammation. Proceedings of the Nutrition Society, 57: 395-401, ISSN: 0029-6651

Scalia, D., Lacetera, N., Bernabucci, U., Demeyere, K., Duchateau, L. \& Burvenich, C. (2006). In vitro effects of non-esterified fatty acids on bovine neutrophils oxidative burst and viability. Journal of Dairy Science 89, pp. 147-154. ISSN: 0022-0302

Schreiber, G.H. \& Schreiber, R.D. (2003). Interferon- $\gamma$. In: The Cytokine Handbook, A.W. Thomson \& M.T. Lotze, (Eds.), Fourth edition, Vol. 1, 567-601. Academic Press, London, UK, ISBN 978-0-12-689663-3.

Sibai, B.M., Caritis, S.N., Thom, E., Klebanoff, M., McNellis, D., Rocco, L., Paul, R.H., Romero, R., Witter, F., Rosen, M. \& Depp R. (1993). Prevention of preeclampsia with low-dose aspirin in healthy, nulliparous pregnant women. The New England Journal of Medicine, 329: 1213-1218, ISSN 0028-4793

Simpson, K.L., Keelan, J.A. \& Mitchell, M.D. (1998). Labor-associated changes in intelreukin10 production and its regulation by immunomodulators in human choriodecidua. Journal of Clinical Endocrinology and Metabolism 83: 4332-4337, ISSN: 0021-972X

Sordillo, L.M., Contreras, G.A. \& Aitken, S.L. (2009). Metabolic factors affecting the inflammatory response of periparturient dairy cows. Animal Health Research Reviews 10:53-63. doi:10.1017/S1466252309990016, ISSN 1466-2523.

Spears, J.W. \& Weiss, P.W. (2008). Role of antioxidants and trace elements in health and immunity of transition dairy cows. Veterinary Journal 176, pp. 70-76. ISSN: 10900233

Suriyasathaporn, W., Daemen, A. J. J. M., Noordhuizen-Stassen, E. N., Dieleman, S. J., Nielen, M. \& Schukken, Y. H. (1999). $\beta$-Hydroxybutyrate levels in peripheral blood and ketone bodies supplemented in culture media affect the in vitro chemotaxis of 
bovine leukocytes. Veterinary Immunology and Immunopathology 68:177-186, ISSN: 0165-2427

Tang, D., Kang, R., Xiao, W., Jiang, L., Liu, M., Shi, Y., Wang, K., Wang, H., \& Xiao, X. (2007). Nuclear heat shock protein 72 as a negative regulator of oxidative stress (hydrogen peroxide)-induced HMGB1 cytoplasmic translocation and release. Journal of Immunology, Vol. 178, pp. 7376-7384, ISSN 0022-1767.

Trevisi, E., Calamari, L., Iamartino, N. \& Bertoni, G. (1998). Sintesi epatiche nel post-parto della bovina: possibili cause di variazione e relazione con la fertilità. Proc. X Meeting Nazionale su "Studio della efficienza riproduttiva degli animali di interesse zootecnico". Bergamo, 12.06.1998, 10: 37-41.

Trevisi, E., Calamari, L. \& Bertoni, G. (2001). Definition of a liver activity index in the transition dairy cow and its relationship with the reproductive performance. Proc. $X$ Int. Symp. of Veterinary Laboratory Diagnosticians, 4-7 July, Salsomaggiore-Parma, Italy, 118-119.

Trevisi, E., Gubbiotti, A. \& Bertoni, G. (2007). Effects of inflammation in peripartum dairy cows on milk yield, energy balance and efficiency. 2nd International Symposium on Energy and Protein Metabolism and Nutrition, Vichy (France), 9-13 Septembre. In "Energy and protein metabolism and nutrition - Eaap 124", edited by: I. OrtiguesMarty, pp. 395-396 ISBN 978-90-8686-041-8.

Trevisi, E., Bakudila, A.M. \& Bertoni, G. (2008a). Modulazione dell'evento infiammatorio nel periparto della bovina da latte mediante la somministrazione di acido acetilsalicilico. Buiatria. Journal of the Italian Association for Buiatrics 3 (2): 61-68.

Trevisi, E., Piccioli-Cappelli, F., Bani, P. \& Bertoni, G. (2008b). Effects of PolinaceaTM extract in periparturient dairy cows. Book of Abstracts of the 59th Annual Meeting of the European Association for Animal Production, Vilnius, Lithuania, 24-27 August, p. 147, ISBN: 978-90-8686-074-6

Trevisi, E. \& Bertoni, G. (2008). Attenuation with acetylsalicylate treatments of inflammatory conditions in periparturient dairy cows. In "Aspirin and health research progress", Nova Science Publishers, Hauppauge, NY, USA. pp 23-37, ISBN 9781604561647

Trevisi, E., Amadori, M., Bakudila, A. \& Bertoni G. (2009). Metabolic changes in dairy cows induced by oral, low-dose interferon-alpha treatment. Journal of Animal Science, Vol. 87 (9), pp. 3020-3029, ISSN 0021-8812.

Trevisi, E., Amadori, M., Cogrossi, S. \& Bertoni G. (2010a). Metabolic stress and interleukin-6 response in high-yielding, periparturient dairy cows. 9th IVIS (International Veterinary Immunology Symposium), August 16-20, 2010, Tokyo, Japan, Page 138.

Trevisi, E., Ferrari, A., Piccioli-Cappelli, F., Grossi, P. \& Bertoni, G. (2010b). An additional study on the relationship between the inflammatory condition at calving time and net energy efficiency in dairy cows. In: "Energy and Protein Metabolism and Nutrition. EAAP publication No. 127". Wageningen Academic Publishers. Pp 489-490, ISBN 978-90-8686-153-8.

Trevisi, E., Zecconi, A., Bertoni, G. \& Piccinini, R. (2010c). Blood and milk immune and inflammatory responses in periparturient dairy cows showing a different liver activity index. Journal of Dairy Research 77: 310-317, ISSN: 0022-0299 
Van Eden, W., Van Der Zee, R. \& Prakken B. (2005). Heat-shock proteins induce T-cell regulation of chronic inflammation. Nature Reviews Immunology, Vol. 5, pp. 318330, ISSN 1474-1733.

Villa-Godoy, A., Hughes, T.L., Emery, R.S., Chapin, L. \& Fogwell, R.L. (1988). Association between energy balance and luteal function in lactating dairy cows. Journal of Dairy Science 71:1063-1072, ISSN: 0022-0302

Wan, J.M., Haw, M. P. \& Blackburn, G.L. (1989). Nutrition, immune function and inflammation: an overview. Symposium on "The interaction between nutrition and inflammation", Proceedings of the Nutrition Society, 48: 315-335, ISSN 0029-6651.

Wathes, D.C., Cheng, Z., Chowdhury, W., Fenwick, M.A., Fitzpatrick, R., Morris, D.G., Patton, J. \& Murphy, J.J. (2009). Negative energy balance alters global gene expression and immune responses in the uterus of postpartum dairy cows. Physiological Genomics 39, 1-13, ISSN: 1094-8341 
ACUTE PHASE PROTEINS AS EARIY NON-SPECIFIC BIOMARKERS OF HUMAN ANO VETERINARY DISEASES

Edited by Francheo Vees

\section{Acute Phase Proteins as Early Non-Specific Biomarkers of Human and Veterinary Diseases}

Edited by Prof. Francisco Veas

\section{ISBN 978-953-307-873-1}

Hard cover, 408 pages

Publisher InTech

Published online 10, October, 2011

Published in print edition October, 2011

The two volumes of Acute Phase Proteins book consist of chapters that give a large panel of fundamental and applied knowledge on one of the major elements of the inflammatory process during the acute phase response, i.e., the acute phase proteins expression and functions that regulate homeostasis. We have organized this book in two volumes - the first volume, mainly containing chapters on structure, biology and functions of APP, the second volume discussing different uses of APP as diagnostic tools in human and veterinary medicine.

\section{How to reference}

In order to correctly reference this scholarly work, feel free to copy and paste the following:

Erminio Trevisi, Massimo Amadori, Ivonne Archetti, Nicola Lacetera and Giuseppe Bertoni (2011). Inflammatory Response and Acute Phase Proteins in the Transition Period of High-Yielding Dairy Cows, Acute Phase Proteins as Early Non-Specific Biomarkers of Human and Veterinary Diseases, Prof. Francisco Veas (Ed.), ISBN: 978-953-307-873-1, InTech, Available from: http://www.intechopen.com/books/acute-phaseproteins-as-early-non-specific-biomarkers-of-human-and-veterinary-diseases/inflammatory-response-andacute-phase-proteins-in-the-transition-period-of-high-yielding-dairy-cows

\section{INTECH}

open science | open minds

\section{InTech Europe}

University Campus STeP Ri Slavka Krautzeka 83/A 51000 Rijeka, Croatia Phone: +385 (51) 770447 Fax: +385 (51) 686166 www.intechopen.com

\section{InTech China}

Unit 405, Office Block, Hotel Equatorial Shanghai No.65, Yan An Road (West), Shanghai, 200040, China 中国上海市延安西路65号上海国际贵都大饭店办公楼405单元 Phone: +86-21-62489820

Fax: +86-21-62489821 
(C) 2011 The Author(s). Licensee IntechOpen. This is an open access article distributed under the terms of the Creative Commons Attribution 3.0 License, which permits unrestricted use, distribution, and reproduction in any medium, provided the original work is properly cited. 